\title{
Extracorporeal Carbon Dioxide Removal During Continuous Renal Replacement Therapy as Adjunctive Therapy
}

\author{
Rita Jacobs, Adriaan Sablon, and Herbert Spapen
}

\author{
Ventilating Patients With Acute Lung Injury \\ Extracorporeal Techniques at the Rescue \\ Lung-Kidney Interaction in ARDS \\ Literature Review \\ Animal Studies \\ Case Reports \\ Retrospective Studies \\ Prospective Trials \\ Summary
}

\begin{abstract}
Lung-protective ventilation targeting low tidal volumes and plateau pressures is the mainstay of therapy in patients with ARDS. This ventilation strategy limits pulmonary strain, inflammation, and injury, but it may be associated with profound hypercapnic acidosis. In such conditions, extracorporeal $\mathrm{CO}_{2}$ removal can attenuate or normalize hypercapnia and may even facilitate ultraprotective ventilation. Almost half of patients with ARDS develop renal failure. Pathophysiological cross-talk between the injured lung and kidney may aggravate global organ failure and weighs negatively on outcomes. A substantial number of patients with ARDS require continuous renal replacement therapy. Systems adapted from conventional renal replacement platforms with blood flows $<500 \mathrm{~mL} / \mathrm{min}$ can achieve significant $\mathrm{CO}_{2}$ elimination. Therefore, incorporating low-flow extracorporeal $\mathrm{CO}_{2}$ removal in a continuous renal replacement therapy circuit is an attractive therapeutic option. We reviewed the relevant literature on combining extracorporeal $\mathrm{CO}_{2}$ removal with continuous renal replacement therapy. Key words: ARDS; acute kidney injury; lung-protective ventilation; hypercapnia; extracorporeal carbon dioxide removal; continuous renal replacement therapy. [Respir Care 2020;65(4):517-524. (C) 2020 Daedalus Enterprises]
\end{abstract}

\section{Ventilating Patients With Acute Lung Injury}

ARDS is a severe form of inflammatory lung injury characterized by decreased lung compliance, hypoxemia, and

\footnotetext{
Drs Jacobs, Sablon, and Spapen are affiliated with the Intensive Care Department, University Hospital, Vrije Universiteit Brussels, Brussels, Belgium.

The authors have disclosed no conflicts of interest.

Correspondence: Herbert Spapen MD PhD, Intensive Care Department, University Hospital Brussels, Vrije Universiteit Brussel, Laarbeeklaan 101, B-1090 Brussels, Belgium. E-mail: herbert.spapen@uzbrussel.be.
}

DOI: $10.4187 /$ respcare. 07290 bilateral alveolar infiltrates on chest radiography. ${ }^{1}$ The mortality rate is high, and invasive mechanical ventilation is required in almost all patients. Lung-protective ventilation is the current standard of mechanical ventilation for patients with ARDS. This ventilation strategy focuses on limiting tidal volume $(6 \mathrm{~mL} / \mathrm{kg}$ predicted body weight $)$ and plateau pressure $\left(<30 \mathrm{~cm} \mathrm{H}_{2} \mathrm{O}\right)$ while recruiting collapsed alveoli and keeping them open throughout the ventilatory cycle. ${ }^{2}$ Compared to conventional ventilation, lung-protective ventilation is associated with lower mortality. This survival benefit is significantly related to tidal volume reduction. ${ }^{3}$ However, even ventilated accordingly, patients still remain exposed to forces that can induce lung injury. ${ }^{4,5}$ Therefore, further reductions in tidal volume $(4 \mathrm{~mL} / \mathrm{kg})$ and 
plateau pressure $\left(\leq 25 \mathrm{~cm} \mathrm{H}_{2} \mathrm{O}\right.$ ) have been proposed. ${ }^{6}$ Reducing alveolar ventilation to minimum values inevitably will enhance $\mathrm{CO}_{2}$ retention. Accumulation of $\mathrm{CO}_{2}$ causes a drop in $\mathrm{pH}$, leading to a state of respiratory acidosis, which may adversely affect cardiovascular, brain, and immune function. ${ }^{7}$

\section{Extracorporeal Techniques at the Rescue}

Venovenous extracorporeal membrane oxygenation (VVECMO) allows adequate oxygenation and ventilation while ventilator-generated pressures and volumes remain drastically reduced. However, results from the recent EOLIA trial suggest that VV-ECMO should be performed only in highvolume expert centers and in patients with ARDS who are severely hypoxemic $\left(\mathrm{P}_{\mathrm{aCO}} / \mathrm{F}_{\mathrm{IO}_{2}}<80 \mathrm{~mm} \mathrm{Hg}\right){ }^{8}$

Over the last decade, extracorporeal $\mathrm{CO}_{2}$ removal has been introduced as an artificial support to control $\mathrm{CO}_{2}$ levels. ${ }^{9,10}$ Unlike VV-ECMO, extracorporeal $\mathrm{CO}_{2}$ removal refers to a low-flow (ie, $0.5-1 \mathrm{~L} / \mathrm{min}$ ) extracorporeal circuit that selectively extracts $\mathrm{CO}_{2}$ from blood and minimally affects oxygenation. Extracorporeal $\mathrm{CO}_{2}$ removal devices include a drainage cannula placed in a central vein (ie, venovenous systems) or artery (ie, arteriovenous systems), an artificial membrane lung, a pump in venovenous configurations, and a return cannula into the venous system.

During extracorporeal $\mathrm{CO}_{2}$ removal, a flow of gas with little or no $\mathrm{CO}_{2}$ (ie, sweep gas) favors $\mathrm{CO}_{2}$ removal from the patient's blood by generating a diffusion gradient across the membrane. ${ }^{11}$ Additional $\mathrm{CO}_{2}$ removal depends on the blood flow to the membrane. An average adult produces about $200-250 \mathrm{~mL} / \mathrm{min} \mathrm{CO}_{2}$ and $1 \mathrm{~L}$ of blood contains approximately $500 \mathrm{~mL} \mathrm{CO}$. Thus, a blood flow of $0.5 \mathrm{~L} / \mathrm{min}$ would theoretically suffice to remove all of the $\mathrm{CO}_{2}$ produced by the body. In practice, however, extracorporeal $\mathrm{CO}_{2}$ removal removes up to $25 \%$ of $\mathrm{CO}_{2}$ production because gas transfer is also influenced by premembranous blood $\mathrm{CO}_{2}$ content, membrane characteristics, and hemoglobin concentration. ${ }^{12}$

Using an extracorporeal $\mathrm{CO}_{2}$ removal system equipped with a silicone rubber membrane oxygenator, Kolobow et $\mathrm{al}^{13}$ were the first to demonstrate that $\mathrm{CO}_{2}$ transfer (35-65 $\mathrm{mL} / \mathrm{min}$ ) at a constant sweep gas flow of $2.5 \mathrm{~L} / \mathrm{min}$ was dependent on blood flows $(400-1,000 \mathrm{~mL} / \mathrm{min})$ and premembrane $\mathrm{P}_{\mathrm{CO}_{2}}$ levels. Cardenas et al, ${ }^{14}$ applying a polypropylene microporous hollow fiber membrane oxygenator, reported that $\mathrm{CO}_{2}$ transfer was directly proportional to blood flow and gas flow, ranging from $31 \mathrm{~mL} / \mathrm{min}$ (at $500 \mathrm{~mL} / \mathrm{min}$ blood flow and $2 \mathrm{~L} / \mathrm{min}$ gas flow) to 150 $\mathrm{mL} / \mathrm{min}$ (at $1,000 \mathrm{~mL} / \mathrm{min}$ blood flow and $15 \mathrm{~L} / \mathrm{min}$ gas flow). In the clinical setting, extracorporeal $\mathrm{CO}_{2}$ removal proved to be effective in 95 subjects with moderate ARDS, achieving ultraprotective settings in $82 \%$ by $24 \mathrm{~h}^{15}$
Karagiannidis et $\mathrm{al}^{16}$ highlighted the essential extracorporeal $\mathrm{CO}_{2}$ removal requirements (ie, choice of cannula and optimal blood and sweep gas flow) for the successful treatment of severe respiratory acidosis. Extracorporeal $\mathrm{CO}_{2}$ removal with a $0.98 \mathrm{~m}^{2}$ surface oxygenator was performed in 6 acidotic $(\mathrm{pH}<7.20)$ pigs using either a 14.5French or a 19-French catheter and applying sweep gas flows of 8 and $16 \mathrm{~L} / \mathrm{min}$, respectively. During each experiment, blood flow was incrementally increased to a maximum of $400 \mathrm{~mL} / \mathrm{min}$ (14.5 French catheter) and 1,000 $\mathrm{mL} / \mathrm{min}$ (19 French catheter). Correction of acidosis was obtained only with the 19-French catheter at blood flows of $750-1,000 \mathrm{~mL} / \mathrm{min}$. Doubling sweep gas flow had less impact on extracorporeal $\mathrm{CO}_{2}$ removal performance.

The same investigators studied the impact of different membrane lungs on $\mathrm{CO}_{2}$ removal. ${ }^{17}$ Extracorporeal $\mathrm{CO}_{2}$ removal was performed in anesthetized and mechanically ventilated pigs that were subjected to severe respiratory acidosis ( $\mathrm{pH} 7.0-7.1)$ using membrane lungs with surface areas of $0.4,0.8,1.0$, and $1.3 \mathrm{~m}^{2}$. A 20-French doublelumen catheter was inserted, and sweep gas flow was set at $8 \mathrm{~L} / \mathrm{min}$. During each experiment, blood flow was increased stepwise from $250 \mathrm{~mL} / \mathrm{min}$ to $1,000 \mathrm{~mL} / \mathrm{min}$. Respiratory acidosis was attenuated only at blood flows of $750-1,000 \mathrm{~mL} / \mathrm{min}$ over a membrane lung surface area of $\geq 0.8 \mathrm{~m}^{2}$. Maximum $\mathrm{CO}_{2}$ elimination with concomitant $\mathrm{pH}$ increase to 7.3 was obtained with the $1.3-\mathrm{m}^{2}$ membrane lung at a blood flow of $1,000 \mathrm{~mL} / \mathrm{min}$. The membrane lung with a surface of $0.4 \mathrm{~m}^{2}$ allowed less than half of this $\mathrm{CO}_{2}$ elimination rate and failed to normalize $\mathrm{pH}$, even when blood flow was $1,000 \mathrm{~mL} / \mathrm{min}$.

\section{Lung-Kidney Interaction in ARDS}

ARDS and mechanical ventilation are independently associated with acute kidney injury (AKI) ${ }^{18}$ Ventilated patients have a 3 -fold increase in the odds ratio of AKI. ${ }^{19}$ Conversely, presence of AKI prolongs ventilator dependence and increases mortality. ${ }^{20}$ During ARDS, renal function is impeded by hemodynamic alterations, ischemic insults, toxic factors, and remote oxidative and neurohormonal stress. ${ }^{21}$ In addition, the kidneys are exposed to injurious inflammation because mechanical ventilation-related overdistention or repetitive alveolar collapse can trigger the systemic release of proinflammatory cytokines and may increase expression of endothelial inflammatory mediators in the kidney. ${ }^{22,23}$

Renal replacement therapy is frequently initiated to treat AKI in patients with ARDS. Among other techniques, continuous renal replacement therapy (CRRT) is increasingly used in ICUs worldwide. CRRT allows constant blood purification, is hemodynamically well tolerated, permits safe fluid titration to achieve optimal hemodynamic and 
nutritional goals, achieves metabolic control more rapidly, and swiftly removes excess fluid. ${ }^{24}$

Extracorporeal $\mathrm{CO}_{2}$ removal and CRRT circuits may be integrated into a global lung and renal support system. No additional vascular access other than the dialysis catheter is required. Any membrane oxygenator or gas exchanger can be implemented in the CRRT circuit. A typical example of combined extracorporeal $\mathrm{CO}_{2}$ removal with CRRT is the DECAP (Hemodec, Salerno, Italy)/DECAPSMART (Medica, Medolla, Modena, Italy) system, which consists of a membrane lung placed in series with a polysulfone hemofilter (surface area of $0.3-1.35 \mathrm{~m}^{2}$ ) (Fig. 1). A roller pump drives blood from the patient to the oxygenator and hemofilter, and $\mathrm{CO}_{2}$ is eliminated by diffusion at a constant flow of air or oxygen through the oxygenator. A second roller pump returns the ultrafiltrate from the filter to the inflow of the oxygenator. The higher flow entering the membrane lung and the recirculation of $\mathrm{CO}_{2}$ dissolved in the ultrafiltrate improve $\mathrm{CO}_{2}$ removal. Additionally, the ultrafiltrate acts as predilution, reducing hematocrit and preventing blood packing. This allows lower flows $(<500 \mathrm{~mL} / \mathrm{min})$ than those used in CRRT but provides anticoagulation therapy similar to that of CRRT. ${ }^{25}$

$\mathrm{CO}_{2}$ removal dramatically declines when blood flow decreases to $300-350 \mathrm{~mL} / \mathrm{min}$. De Bels et al ${ }^{26}$ developed a

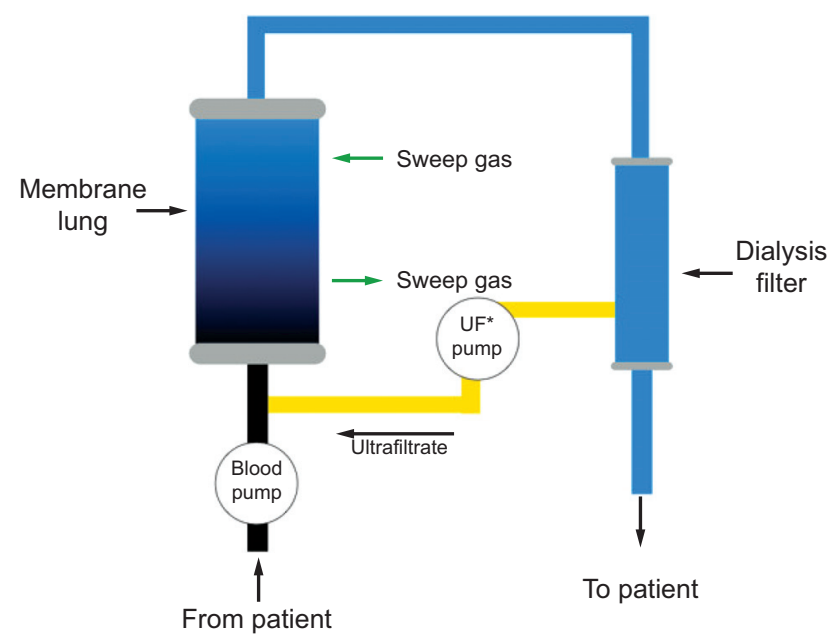

Fig. 1. Diagram showing the basic circuit design of the DECAP system. novel approach to run extracorporeal $\mathrm{CO}_{2}$ removal at a blood flow of $450 \mathrm{~mL} / \mathrm{min}$ within a CRRT circuit. To achieve such blood flow, 2 double-lumen catheters (13 French) were inserted, one in the jugular vein and one in the femoral vein. The catheters were linked with a Y-adapter to create a single bloodline without loss of blood flow. Blood was extracted from the CRRT-extracorporeal $\mathrm{CO}_{2}$ removal system via the femoral catheter and, after decarboxylation, reinfused through the cephalic catheter. Compared with to a single-catheter approach, blood flow increased by almost $40 \%$, which permitted CRRT-extracorporeal $\mathrm{CO}_{2}$ removal to run for up to $72 \mathrm{~h}$ in the majority of cases.

\section{Literature Review}

We conducted a PubMed and MEDLINE literature search for studies investigating CRRT-extracorporeal $\mathrm{CO}_{2}$ removal as a way to facilitate lung-protective ventilation. Only articles in English published in peer-reviewed journals were considered. We used the following search items: (carbon dioxide[MeSH Terms] OR (carbon[All Fields] AND dioxide[All Fields]) OR carbon dioxide[All Fields]) AND removal[All Fields] AND continuous[All Fields] AND (renal replacement therapy[MeSH Terms] OR (renal[All Fields] AND replacement[All Fields] AND therapy[All Fields]) OR renal replacement therapy[All Fields]). Related articles were used to broaden the search, and citations were scanned for relevance. The last search was performed on June 30, 2019. We initially identified 110 papers, of which 94 were discarded after screening the abstract or the article content. From the remaining 16 studies, 13 were used in our final analysis, including 4 preclinical studies, 3 case reports, 3 retrospective studies, and 3 prospective clinical trials.

\section{Animal Studies}

Of the 4 preclinical studies, 3 were performed in sheep and 1 was performed in pigs under conditions of normal physiology; in 2 of these studies, hypercapnia was induced (Table 1). Livigni et al $^{27}$ quantified $\mathrm{CO}_{2}$ removal of an extracorporeal membrane gas exchanger placed in a venovenous pump-driven bypass (DECAPSMART) in 7 adult sheep. $\mathrm{CO}_{2}$ was continuously cleared from the circulation

Table 1. Animal Studies

\begin{tabular}{lccclc}
\hline \hline \multicolumn{1}{c}{ Study } & Animals, no. & Blood Flow, L/min & Gas Flow, L/min & Result & Adverse Events \\
\hline Livigni et $\mathrm{al}^{27}$ & 7 & 300 & Not reported & $\mathrm{CO}_{2}$ reduced by 17-22\% & No \\
Godet et al $^{28}$ & 5 & $200,300,400$ & Not reported & $\mathrm{CO}_{2}$ removal rates $35-75 \mathrm{~mL} / \mathrm{min}$ & Not reported \\
Young et al $^{29}$ & 9 & $470-600$ & 10 & $\mathrm{CO}_{2}$ elimination 130-180 mL/min & Not reported \\
Scaravilli et al $^{30}$ & 3 & 250 & 10 & $\mathrm{CO}_{2}$ removal not influenced by ultrafiltrate recirculation & No \\
\hline
\end{tabular}


EXTRACORPOREAL $\mathrm{CO}_{2}$ REMOVAL AND CRRT

Table 2. Case Reports

\begin{tabular}{|c|c|c|c|c|c|c|}
\hline Study & Condition & $\begin{array}{l}\text { Blood Flow, } \\
\text { L/min }\end{array}$ & $\begin{array}{l}\text { Gas Flow, } \\
\text { L/min }\end{array}$ & Result & Outcome & $\begin{array}{l}\text { Adverse } \\
\text { Effects }\end{array}$ \\
\hline $\begin{array}{l}\text { Gramaticopolo } \\
\quad \text { et } \mathrm{al}^{25}\end{array}$ & Septic shock & $350-380$ & $10(\mathrm{FF} 20 \%)$ & $\begin{array}{l}\text { Pressure support reduced from } 12 \text { to } 10 \mathrm{~cm} \mathrm{H}_{2} \mathrm{O} \\
\text { Peak pressure reduced from } 33 \text { to } 26 \mathrm{~cm} \mathrm{H}_{2} \mathrm{O} \\
\text { Renal function improved }\end{array}$ & Alive & Not reported \\
\hline \multirow[t]{2}{*}{ Grant et $\mathrm{a}^{31}$} & Sepsis, ARDS & Not reported & Not reported & $\begin{array}{l}\mathrm{pH} \text { increased from } 7.33 \text { to } 7.37 \\
\mathrm{P}_{\mathrm{aCO}_{2}} \text { reduced from } 48 \text { to } 44 \mathrm{~mm} \mathrm{Hg}\end{array}$ & Alive & Not reported \\
\hline & $\begin{array}{l}\text { Sepsis, AKI, } \\
\text { ARDS }\end{array}$ & Not reported & Not reported & $\begin{array}{l}\mathrm{pH} \text { increased from } 7.1 \text { to } 7.4 \\
\mathrm{P}_{\mathrm{aCO}_{2}} \text { reduced from } 56 \text { to } 34 \mathrm{~mm} \mathrm{Hg}\end{array}$ & Alive & Not reported \\
\hline Morris et $\mathrm{al}^{32}$ & $\begin{array}{l}\text { Sepsis, AKI, } \\
\text { ARDS }\end{array}$ & Not reported & Not reported & $\mathrm{P}_{\mathrm{aCO}}$ reduced from 63 to $40-50 \mathrm{~mm} \mathrm{Hg}$ & Died & No \\
\hline $\begin{array}{l}\mathrm{FF}=\text { filtration frac } \\
\mathrm{AKI}=\text { acute kidne }\end{array}$ & & & & & & \\
\hline
\end{tabular}

and on average reduced from baseline by $17-22 \% . \mathrm{P}_{\mathrm{aCO}_{2}}$ returned to baseline after treatment discontinuation.

Godet et $\mathrm{al}^{28}$ studied 5 hypercapnic pigs equipped with a low-flow $\mathrm{CO}_{2}$ removal device (PrismaLung) integrated on a CRRT platform (PrismaFlex). A polymethylpentene infant hollow fiber gas exchanger (Medos Hilite 1800 LT) with a surface area of $0.32 \mathrm{~m}^{2}$ was used as the decarboxylation filter. Sweep gas was adjusted to flows of 2, 5, 10, and $50 \mathrm{~L} / \mathrm{min}$. Blood flows were randomly set at 200, 300, and $400 \mathrm{~mL} / \mathrm{min}$. Gas analysis before and after the gas exchanger showed a significant reduction in $\mathrm{P}_{\mathrm{aCO}_{2}}$ of $40.2 \pm$ $13.0 \mathrm{~mm} \mathrm{Hg}$ and an increase in $\mathrm{pH}$ of $0.24 \pm 0.06$. After 10 min of treatment, $\mathrm{P}_{\mathrm{aCO}_{2}}$ decreased from $81.2 \mathrm{~mm} \mathrm{Hg}$ to 70.0 $\mathrm{mm} \mathrm{Hg}$ and $\mathrm{pH}$ increased from 7.17 to $7.22 . \mathrm{CO}_{2}$ removal rates ranged from 35 to $75 \mathrm{~mL} / \mathrm{min}$. At the lowest blood flow, $\mathrm{CO}_{2}$ removal rates remained constant and independent from sweep gas flow rising from $2 \mathrm{~L} / \mathrm{min}$ to $10 \mathrm{~L} / \mathrm{min}$. At 300 and $400 \mathrm{~mL} / \mathrm{min}$ blood flow, $\mathrm{CO}_{2}$ removal rates increased with sweep gas flows, reaching a plateau between 10 and $50 \mathrm{~L} / \mathrm{min}$.

Young et $\mathrm{al}^{29}$ investigated 9 sheep, using a $5-\mathrm{m}^{2}$ hollow fiber membrane lung with countercurrent gas flow (Capiox 350) combined with an hemofiltration blood pump (Dialysatoren) to flow through femoral arterial and venous hemodialysis catheters. A blood flow of 470-600 mL/min and a gas flow of $10 \mathrm{~L} / \mathrm{min}$ guaranteed satisfactory $\mathrm{CO}_{2}$ elimination (130-180 $\mathrm{mL} / \mathrm{min})$.

Ultrafiltrate recirculation may mitigate hemostasis through the membrane oxygenator and abate circuitrelated inflammation. Scaravilli et $\mathrm{al}^{30}$ were the first to examine the effects of such recirculation on $\mathrm{CO}_{2}$ removal capability. Three conscious spontaneously breathing sheep were connected to an extracorporeal $\mathrm{CO}_{2}$ removal device (Hemolung) installed at a blood flow of $250 \mathrm{~mL} / \mathrm{min}$ and a gas flow of $10 \mathrm{~L} / \mathrm{min}$. A hemofilter (NxStage) placed in series with the membrane lung generated ultrafiltrate that was recirculated upstream to the membrane lung. Increas- ing ultrafiltrate flow progressively lowered premembrane blood $\mathrm{CO}_{2}$ concentrations. The corresponding observed reduction in membrane $\mathrm{CO}_{2}$ removal efficiency was countered by the increased (blood + ultrafiltrate) flow passing through the membrane and finally resulted in constant $\mathrm{CO}_{2}$ elimination $(40.5 \pm 4.0,39.7 \pm 4.2,39.8 \pm 4.2$, and $39.2 \pm 4.1 \mathrm{~mL} / \mathrm{min}$ at ultrafiltrate flows of $0,50,100$, and $150 \mathrm{~mL} / \mathrm{min}$, respectively). Thus, application of ultrafiltrate recirculation did not alter $\mathrm{CO}_{2}$ removal compared with no recirculation and, as a direct result, did not affect the animals' ventilatory patterns or arterial blood gas values.

In summary, animal studies generally reported substantial reductions in $\mathrm{CO}_{2}$ volume and $\mathrm{P}_{\mathrm{aCO}}$. The magnitude of $\mathrm{CO}_{2}$ removal appeared to depend upon both dialysis blood flow and sweep gas flow. Effectiveness of $\mathrm{CO}_{2}$ removal reached a plateau at sweep gas flows of $10-50 \mathrm{~L} / \mathrm{min}$ and was not influenced by ultrafiltrate recirculation.

\section{Case Reports}

Three case reports described the application of combined CRRT-extracorporeal $\mathrm{CO}_{2}$ removal in patients with septic shock complicated by respiratory and renal failure (Table 2). Gramaticopolo et $\mathrm{al}^{25}$ observed a progressive decrease of ventilator support and stable $\mathrm{pH}$ in a moderately hypercapnic man with septic shock and multi-organ failure who underwent DECAP plus CRRT for $12 \mathrm{~h}$. Blood flow was kept at 350-380 mL/min, and gas flow was maintained at $10 \mathrm{~L} / \mathrm{min}$. At the end of treatment, renal function recovered, and protective ventilation could be continued without extracorporeal support.

Grant et $\mathrm{al}^{31}$ reported a female kidney transplant patient with pulmonary septic shock and ARDS and a male patient with postoperative sepsis, AKI, and respiratory failure. In both patients, lung-protective ventilation provided acceptable oxygenation at the cost of severe 
Table 3. Retrospective Studies

\begin{tabular}{|c|c|c|c|c|c|c|c|}
\hline Study & $\begin{array}{c}\text { Subjects, } \\
\quad N\end{array}$ & Condition & $\begin{array}{l}\text { Blood Flow, } \\
\text { L/min }\end{array}$ & $\begin{array}{l}\text { Gas Flow, } \\
\text { L/min }\end{array}$ & Result & Outcome & $\begin{array}{c}\text { Adverse } \\
\text { Events }\end{array}$ \\
\hline $\begin{array}{l}\text { Quintard } \\
\text { et } \mathrm{al}^{33}\end{array}$ & 16 & $\begin{array}{l}\text { Respiratory } \\
\text { acidosis, AKI }\end{array}$ & $400-500$ & 10 & $\begin{array}{l}\text { Mean } \mathrm{P}_{\mathrm{aCO}} \text { reduction of } 31 \% \text { and } \\
39 \% \text { at } 6 \mathrm{~h} \text { and } 12 \mathrm{~h} \text {, respectively, } \\
\text { with concomitant } \mathrm{pH} \text { increase }\end{array}$ & 7 subjects died & No \\
\hline Forster et $\mathrm{al}^{34}$ & 10 & ARDS & $\begin{array}{l}250-500 \\
\quad(\text { mean } 378)\end{array}$ & Not reported & $\begin{array}{l}28 \% \text { mean } \mathrm{P}_{\mathrm{aCO}} \text { reduction } \\
65 \% \text { reduction of vasopressors }\end{array}$ & 3 subjects died & $\begin{array}{l}2 \text { filters } \\
\text { clotted }\end{array}$ \\
\hline Moerer et $\mathrm{al}^{35}$ & 11 & $\begin{array}{l}\text { Mixed } \\
\text { population }\end{array}$ & 300 & 10 & $\begin{array}{l}\text { Mean } \mathrm{P}_{\mathrm{aCO}_{2}} \text { reduction from } 34.4 \text { to } \\
28.8 \mathrm{~mm} \mathrm{Hg} \text { at } 1 \mathrm{~h} \text { and to } \\
31.6 \mathrm{~mm} \mathrm{Hg} \text { at } 6 \mathrm{~h}\end{array}$ & Not reported & No \\
\hline
\end{tabular}

$\overline{\mathrm{AKI}}=$ acute kidney injury

hypercapnia. A low-flow membrane oxygenator (CapiOx RX05) placed in line with a continuous venovenous hemodialysis circuit (NxStage System One renal replacement device) resulted in an immediate and sustained drop in $\mathrm{P}_{\mathrm{aCO}}$, $\mathrm{pH}$ normalization, and subsequent hemodynamic stabilization.

Morris et $\mathrm{al}^{32}$ reported improved $\mathrm{CO}_{2}$ removal in a 6-yold boy with postoperative anasarca, sepsis-induced hepatorenal syndrome, and ARDS after adding a membrane oxygenator (CB Minimax or Lilliput I) before the filter of a continuous venovenous hemodialysis circuit. In summary, these case studies reported that combined CRRTextracorporeal $\mathrm{CO}_{2}$ removal substantially curbed hypercapnia and facilitated lung-protective ventilation in critically ill patients.

\section{Retrospective Studies}

Three retrospective studies were conducted in mechanically ventilated subjects. Two studies included subjects with ARDS and refractory hypercapnia due to COPD exacerbation, and one study investigated a mixed patient population with AKI undergoing lung-protective ventilation (Table 3). Quintard et al ${ }^{33}$ studied 16 mechanically ventilated subjects with persistent significant respiratory acidosis and AKI necessitating CRRT (either continuous venovenous hemodialysis or continuous venovenous hemofiltration). A, rheoparine-coated, polypropylene oxygenation membrane with a surface area of $0.65 \mathrm{~m}^{2}$ (Hilite 2400 LT) was introduced into the CRRT circuit in serial manner and upstream from the hemofilter. Unfractionated heparin was used for anticoagulation (target activated partial thromboplastin time, 45-50 s). Blood flow and sweep gas flow were set at $400 \mathrm{~mL} / \mathrm{min}$ and 10 $\mathrm{L} / \mathrm{min}$, respectively. The mean $\mathrm{P}_{\mathrm{aCO}}$ level before treatment was 77.3 (range 59-112) mm Hg. Adequate blood flow was achieved either with one femoral 16-French dual-lumen catheter or with two 13.5-French doublelumen catheters in the jugular and femoral positions.
Mean $\mathrm{P}_{\mathrm{aCO}}$ reduction was $24.4 \mathrm{~mm} \mathrm{Hg}(31 \%)$ after $6 \mathrm{~h}$ and $30 \mathrm{~mm} \mathrm{Hg}$ after $12 \mathrm{~h}(39 \%)$. Mean $\mathrm{pH}$ increase was 0.16 at $6 \mathrm{~h}$ and 0.23 at $12 \mathrm{~h}$. Lung-protective ventilation was maintained in all subjects. Treatment was safe and hemodynamically well tolerated.

Forster et $\mathrm{al}^{34}$ evaluated 10 critically ill subjects with ARDS and AKI. CRRT was initiated with a continuous venovenous hemodialysis device (bm11/14) equipped with a high-flux polysulfone capillary hemofilter with a membrane surface area of $1.4 \mathrm{~m}^{2}$ (Polyflux 140H). Extracorporeal $\mathrm{CO}_{2}$ removal was provided by a hollow-fiber gas exchanger (D902 Liliput 2 ECMO) placed after the dialysis filter. Gas flow through the gas exchanger was set at $4 \mathrm{~L} / \mathrm{min}$ with blood flows $<300 \mathrm{~mL} / \mathrm{min}$ or at $4-6 \mathrm{~L} / \mathrm{min}$ when blood flows exceeded $300 \mathrm{~mL} / \mathrm{min}$. A 13.5-French double-lumen catheter was placed in the jugular vein. In 2 subjects, a second 13.5-French double-lumen catheter was inserted in the femoral vein to allow higher blood flows. The 2 lumina of one catheter were linked with a Y-adapter to form a single bloodline. Blood flows of $250-500 \mathrm{~mL} / \mathrm{min}$ could be achieved in all subjects. After $4 \mathrm{~h}$ of treatment, a mean $\mathrm{P}_{\mathrm{aCO}_{2}}$ reduction of $17.3 \mathrm{~mm} \mathrm{Hg}$ $(28.1 \%)$ was observed with a concomitant $\mathrm{pH}$ increase of 0.12 . A $65 \%$ average reduction of vasopressor dose was obtained in 5 of 6 catecholamine-dependent subjects during the first $24 \mathrm{~h}$.

Moerer et $\mathrm{al}^{35}$ conducted a study in 11 ventilated subjects with AKI on either pre- or postdilution CRRT running in continuous venovenous hemodiafiltration mode. A minimum-flow extracorporeal $\mathrm{CO}_{2}$ removal (EQUA-smart) device was added to the circuit for $6 \mathrm{~h}$. This combined CRRT-extracorporeal $\mathrm{CO}_{2}$ removal system safely and significantly decreased minute ventilation, tidal volume, and $\mathrm{P}_{\mathrm{aCO}}$ during the first hours of therapy, but it was not able to improve or preserve this result throughout the trial. Average total $\mathrm{CO}_{2}$ removal reached $20.7 \mathrm{~mL} / \mathrm{min}$, with comparable values between pre- and postdilution. The system failed to significantly reduce lung stress due to ventilator settings. 
EXTRACORPOREAL $\mathrm{CO}_{2}$ REMOVAL AND CRRT

Table 4. Prospective Studies

\begin{tabular}{|c|c|c|c|c|c|c|c|}
\hline Study & $\begin{array}{c}\text { Subjects, } \\
\quad N\end{array}$ & Condition & $\begin{array}{l}\text { Blood Flow, } \\
\text { L/min }\end{array}$ & $\begin{array}{l}\text { Gas Flow, } \\
\text { L/Min }\end{array}$ & Result & Outcome & $\begin{array}{l}\text { Adverse } \\
\text { Events }\end{array}$ \\
\hline $\begin{array}{l}\text { Allardet-Servent } \\
\text { et }^{3 l^{36}}\end{array}$ & 11 & ARDS & $\begin{array}{l}\text { Downstream } \\
\quad 410 \pm 30 \\
\text { Upstream } 432 \pm 25\end{array}$ & Not reported & $\begin{array}{l}\mathrm{CO}_{2} \text { removal rate } \\
\quad 83 \pm 20 \mathrm{~mL} / \mathrm{min}\end{array}$ & $\begin{array}{l}8 \text { subjects survived } \\
\text { to extracorporeal } \\
\mathrm{CO}_{2} \text { removal } \\
9 \text { subjects died in } \\
\text { ICU }\end{array}$ & 1 filter clotted \\
\hline Nentwich et $\mathrm{al}^{37}$ & 20 & $\begin{array}{l}\text { Hypercapnic } \\
\text { critically ill } \\
\text { subjects } \\
\text { with } \\
\text { renal failure }\end{array}$ & $\begin{array}{c}\text { Mean extracorporeal } \\
\mathrm{CO}_{2} \text { removal } \\
43.4 \pm 14.1\end{array}$ & 8 & $\begin{array}{c}\text { Mean } \mathrm{P}_{\mathrm{aCO}_{2}} \text { reduction } \\
\text { from } 68.3 \pm 11.8 \text { to } \\
61.8 \pm 11.5 \mathrm{~mm} \mathrm{Hg} \\
\text { Mean pH increased } \\
\text { from } 7.18 \pm 0.09 \text { to } \\
7.22 \pm 0.08\end{array}$ & 2 subjects died & 5 filters clotted \\
\hline Schmidt et $\mathrm{al}^{38}$ & 20 & ARDS & Mean $421 \pm 40$ & Mean $10 \pm 0.3$ & $\begin{array}{r}\text { Mean } \mathrm{CO}_{2} \text { removal } \\
51 \pm 26 \mathrm{~mL} / \mathrm{min}\end{array}$ & 28 -d mortality $15 \%$ & $\begin{array}{l}10 \text { filters clotted, } \\
2 \text { instances of } \\
\text { hemoptysis }\end{array}$ \\
\hline
\end{tabular}

Taken together, combining extracorporeal $\mathrm{CO}_{2}$ removal with CRRT in hypercapnic subjects with ARDS or COPD caused a $\mathrm{P}_{\mathrm{aCO}}$, reduction of up to $30 \%$ and significantly increased $\mathrm{pH}$. In AKI subjects undergoing lung-protective ventilation, an initial decrease in $\mathrm{P}_{\mathrm{aCO}}$ was not sustained, and ventilator-induced lung stress remained unchanged. The application of CRRT-extracorporeal $\mathrm{CO}_{2}$ removal either in pre- or postdilution mode was safe and hemodynamically well tolerated.

\section{Prospective Trials}

The 3 prospective studies identified in the literature search primarily enrolled subjects with ARDS (Table 4). Allardet-Servent studied 11 subjects with ARDS and AKI requiring CRRT. ${ }^{36}$ CRRT was provided as continuous venovenous hemofiltration and delivered with a PrismaFlex 6.0 CRRT platform titrated to maintain a maximum blood flow and an effluent flow of $45 \mathrm{~mL} / \mathrm{kg} / \mathrm{h}$ with a $33 \%$ predilution rate. A $0.65-\mathrm{m}^{2}$ polymethylpentene heparin-coated hollow fiber membrane oxygenator (Hilite $2400 \mathrm{LT}$ ) was inserted either upstream or downstream of the hemofilter. Twelve combined therapies were conducted, of which 7 lasted $72 \mathrm{~h}$. At tidal volumes of $6 \mathrm{~mL} / \mathrm{kg}, \mathrm{P}_{\mathrm{aCO}}$ decreased by $21 \%$ (from $47 \pm 11$ to $37 \pm 8 \mathrm{~mm} \mathrm{Hg}$ ). Lowering tidal volume to 4 $\mathrm{mL} / \mathrm{kg}$ raised $\mathrm{P}_{\mathrm{aCO}_{2}}$ from $37 \pm 8$ to $48 \pm 10 \mathrm{~mm} \mathrm{Hg}$. $\mathrm{pH}$ behavior was inversely correlated with changes in $\mathrm{P}_{\mathrm{aCO}_{2}}$. Blood flow and $\mathrm{CO}_{2}$ removal rates tended to be higher when the membrane oxygenator was placed upstream of the filter.

Nentwich et $\mathrm{al}^{37}$ enrolled 20 hypercapnic critically ill subjects in a multicenter observational pilot study for combination treatment incorporating a $0.32-\mathrm{m}^{2}$ membrane oxygenator (Prismalung) in a conventional CRRT circuit in continuous venovenous hemofiltration $\mathrm{F}$ mode
(Prismaflex system). The membrane oxygenator was serially inserted in the CRRT circuit downstream of the hemofilter. Implementation of this extracorporeal $\mathrm{CO}_{2}$ removal system significantly decreased $\mathrm{P}_{\mathrm{aCO}}$ (from $68.3 \pm$ 11.8 to $61.8 \pm 11.5 \mathrm{~mm} \mathrm{Hg}$ and attenuated acidosis $(\mathrm{pH}$ increase from 7.18 to 7.22 ). Tidal volumes, plateau pressures, and pulmonary strain all significantly decreased.

Schmidt et $\mathrm{al}^{38}$ conducted a pilot trial in 5 medical and surgical ICUs, which included 20 subjects with mild or moderate ARDS. Extracorporeal $\mathrm{CO}_{2}$ removal was performed with a low-flow $\mathrm{CO}_{2}$ removal device (Prismalung) integrated into the Prismaflex platform. Standalone extracorporeal $\mathrm{CO}_{2}$ removal with no hemofilter associated within the CRRT platform was initiated when $\mathrm{P}_{\mathrm{aCO}}$ increased $>$ $20 \%$ from baseline. This system easily and safely enabled very low tidal volume ventilation at higher PEEP levels and significantly decreased plateau and driving pressures.

Taken together, these prospective trials confirm that CRRT-extracorporeal $\mathrm{CO}_{2}$ removal systems can perform safe and adequate $\mathrm{CO}_{2}$ removal, thereby facilitating or enhancing lung-protective ventilation at lower pulmonary strain.

\section{Summary}

Ventilation-induced respiratory acidosis and AKI during the course of acute respiratory failure can be managed simultaneously by integrating extracorporeal $\mathrm{CO}_{2}$ removal into a standard CRRT platform. Results of animal studies, patient case studies, and retrospective clinical trials indicate that implementation of this technique is feasible, safe, and effective. Current evidence from prospective clinical pilot studies is still limited but highlights that substantial $\mathrm{CO}_{2}$ clearance is achieved when blood flows of $400-450 \mathrm{~mL} / \mathrm{min}$ and a sweep gas flow of $10 \mathrm{~L} / \mathrm{min}$ are applied. To date, the best studied setup 


\section{EXTRACORPOREAL $\mathrm{CO}_{2}$ REMOVAL AND CRRT}

that allows or facilitates adequate protective and even ultraprotective ventilation with the least pulmonary compromise uses a $0.32-\mathrm{m}^{2}$ membrane oxygenator integrated in the Prismaflex platform. Technical considerations and progress may contribute to a more patienttailored approach or improve system performance and safety. $\mathrm{CO}_{2}$ removal is enhanced by using a larger membrane surface or by positioning the membrane upstream from the hemofilter. Regional circuit anticoagulation may improve filter life span and decrease the incidence of membrane clotting. A double-catheter approach to run extracorporeal $\mathrm{CO}_{2}$ removal at higher blood flow within a CRRT circuit has been proposed. Large, prospective, and controlled studies are needed to assess the real impact of combined lung-renal support on patient outcome.

\section{REFERENCES}

1. Fan E, Brodie D, Slutsky AS. Acute respiratory distress syndrome: advances in diagnosis and treatment. JAMA 2018;319(7):698710 .

2. Acute Respiratory Distress Syndrome Network. Ventilation with lower tidal volumes as compared with traditional tidal volumes for acute lung injury and the acute respiratory distress syndrome. N Engl J Med 2000;342:1301-1308.

3. Walkey AJ, Goligher EC, Del Sorbo L, Hodgson CL, Adhikari NKJ, Wunsch $\mathrm{H}$, et al. Low tidal volume versus non-volume-limited strategies for patients with acute respiratory distress syndrome: a systematic review and meta-analysis. Ann Am Thorac Soc 2017;14(Suppl 4): S271-S279.

4. Terragni PP, Rosboch G, Tealdi A, Corno E, Menaldo E, Davini O, et al. Tidal hyperinflation during low tidal volume ventilation in acute respiratory distress syndrome. Am J Respir Crit Care Med 2007;175 (2): $160-166$

5. Bellani G, Guerra L, Musch G, Zanella A, Patroniti N, Mauri T, et al. Lung regional metabolic activity and gas volume changes induced by tidal ventilation in patients with acute lung injury. Am J Respir Crit Care Med 2011;183(9):1193-1199.

6. Retamal J, Libuy J, Jiménez M, Delgado M, Besa C, Bugedo G, Bruhn A. Preliminary study of ventilation with $4 \mathrm{~mL} / \mathrm{kg}$ tidal volume in acute respiratory distress syndrome: feasibility and effects on cyclic recruitment - derecruitment and hyperinflation. Crit Care 2013;17 (1):R16.

7. Curley G, Contreras MM, Nichol AD, Higgins BD, Laffey JG. Hypercapnia and acidosis in sepsis: a double-edged sword? Anesthesiology 2010;112(2):462-472.

8. Combes A, Hajage D, Capellier G, Demoule A, Lavoué S, Guervilly C, et al. Extracorporeal membrane oxygenation for severe acute respiratory distress syndrome. N Engl J Med 2018;378(21):1965-1975.

9. Bein T, Weber-Carstens S, Goldmann A, Müller T, Staudinger T, Brederlau J, et al. Lower tidal volume strategy $(\approx 3 \mathrm{ml} / \mathrm{kg})$ combined with extracorporeal $\mathrm{CO} 2$ removal versus 'conventional' protective ventilation $(6 \mathrm{~mL} / \mathrm{kg})$ in severe ARDS: the prospective randomized Xtravent-study. Intensive Care Med 2013;39(5):847-856.

10. Fanelli V, Ranieri MV, Mancebo J, Moerer O, Quintel M, Morley S, et al. Feasibility and safety of low-flow extracorporeal carbon dioxide removal to facilitate ultra-protective ventilation in patients with moderate acute respiratory distress syndrome. Crit Care 2016;20:36
11. Cove ME, MacLaren G, Federspiel WJ, Kellum JA. Bench to bedside review: extracorporeal carbon dioxide removal, past, present and future. Crit Care 2012;16(5):232.

12. de Villiers Hugo J, Sharma AS, Ahmed U, Weerwind PW. Quantification of carbon dioxide removal at low sweep gas and blood flows. J Extra Corpor Technol 2017;49(4):257-261.

13. Kolobow T, Gattinoni L, Tomlinson T, White D, Pierce J, Iapichino G. The carbon dioxide membrane lung (CDML): a new concept. Trans Am Soc Artif Intern Organs 1977;23:17-21.

14. Cardenas VJJr, Miller L, Lynch JE, Anderson MJ, Zwischenberger JB. Percutaneous venovenous $\mathrm{CO} 2$ removal with regional anticoagulation in an ovine model. ASAIO J 2006;52(4):467-470.

15. Combes A, Fanelli V, Pham T, Ranieri VM, European Society of Intensive Care Medicine Trials Group, and the Strategy of UltraProtective Lung Ventilation With Extracorporeal CO2 Removal for New-Onset Moderate to Severe ARDS (SUPERNOVA) Investigators. Feasibility and safety of extracorporeal $\mathrm{CO}(2)$ removal to enhance protective ventilation in acute respiratory distress syndrome: the SUPERNOVA study. Intensive Care Med 2019;45 (5):592-600.

16. Karagiannidis C, Kampe KA, Sipmann FS, Larsson A, Hedenstierna $\mathrm{G}$, Windisch W, Mueller T. Veno-venous extracorporeal CO2 removal for the treatment of severe respiratory acidosis: pathophysiological and technical considerations. Crit Care 2014;18(3):R124.

17. Karagiannidis C, Strassmann S, Brodie D, Ritter P, Larsson A, Borchardt R, Windisch W. Impact of membrane lung surface area and blood flow on extracorporeal $\mathrm{CO} 2$ removal during severe respiratory acidosis. Intensive Care Med Exp 2017;5(1):34

18. Darmon M, Clec'h C, Adrie C, Argaud L, Allaouchiche B, Azoulay E, et al. Acute respiratory distress syndrome and risk of AKI among critically ill patients. Clin J Am Soc Nephrol 2014;9(8):1347-1353.

19. van den Akker JP, Egal M, Groeneveld AB. Invasive mechanical ventilation as a risk factor for acute kidney injury in the critically ill: a systematic review and meta-analysis. Crit Care 2013;17(3): R98.

20. Lombardi R, Nin N, Lorente JA, Frutos-Vivar F, Ferguson ND, Hurtado J, et al. An assessment of the Acute Kidney Injury Network creatinine-based criteria in patients submitted to mechanical ventilation. Clin J Am Soc Nephrol 2011;6(7):1547-1555.

21. Husain-Syed F, Slutsky AS, Ronco C. Lung-kidney cross-talk in the critically ill patient. Am J Respir Crit Care Med 2016;194(4):402414.

22. Kuiper JW, Vaschetto R, Della Corte F, Plötz FB, Groeneveld AB. Bench-to-bedside review: Ventilation-induced renal injury through systemic mediator release-just theory or a causal relationship?. Crit Care 2011:15(4):228

23. Hepokoski M, Englert JA, Baron RM, Crotty-Alexander LE, Fuster MM, Beitler JR, et al. Ventilator-induced lung injury increases expression of endothelial inflammatory mediators in the kidney. Am J Physiol Renal Physiol 2017;312(4):F654-F660.

24. Ricci Z, Romagnoli S, Ronco C. Renal replacement therapy. F1000Res 2016;5:103.

25. Gramaticopolo S, Chronopoulos A, Piccinni P, Nalesso F, Brendolan $\mathrm{A}$, Zanella $\mathrm{M}$, et al. Extracorporeal $\mathrm{CO} 2$ removal-a way to achieve ultraprotective mechanical ventilation and lung support: the missing piece of multiple organ support therapy. Contrib Nephrol 2010;165: 174-184.

26. De Bels D, Pierrakos C, Spapen HD, Honore PM. A double catheter approach for extracorporeal $\mathrm{CO} 2$ removal integrated within a continuous renal replacement circuit. J Transl Int Med 2018;6 (4): 157-158.

27. Livigni S, Maio M, Ferretti E, Longobardo A, Potenza R, Rivalta L, et al. Efficacy and safety of a low-flow veno-venous carbon dioxide 


\section{EXTRACORPOREAL $\mathrm{CO}_{2}$ REMOVAL AND CRRT}

removal device: results of an experimental study in adult sheep. Crit Care 2006;10(5):R151.

28. Godet T, Combes A, Zogheib E, Jabaudon M, Futier E, Slutsky AS, Constantin JM. Novel CO2 removal device driven by a renal-replacement system without hemofilter. A first step experimental validation. Anaesth Crit Care Pain Med 2015;34(3):135-140.

29. Young J, Dorrington K, Blake G, Ryder W. Femoral arterio-venous extracorporeal carbon dioxide elimination using low blood flow. Crit Care Med 1992;20(6):805-809.

30. Scaravilli V, Kreyer S, Linden K, Belenkiy S, Jordan B, Pesenti A, et al. Modular extracorporeal life support: effects of ultrafiltrate recirculation on the performance of an extracorporeal carbon dioxide removal device. ASAIO J 2014;60(3):335-341.

31. Grant AA, Hart VJ, Lineen EB, Forsberg BC, Klima A, Mirsaeidi M, et al. Rescue therapy for hypercapnia due to high PEEP mechanical ventilation in patients with ARDS and renal failure. Artif Organs 2019;43(6):599-604.

32. Morris JL, Rosen DA, Calvert KS, Gustafson RA, Steelman RJ, Rosen KR, Muchant DG. Extracorporeal CO2 removal in a child with a single ventricle by the addition of an oxygenator to a dialysis circuit. Pediatr Crit Care Med 2003;4(1):104-106.

33. Quintard JM, Barbot O, Thevenot F, de Matteis O, Benayoun L, Leibinger F. Partial extracorporeal carbon dioxide removal using a standard continuous renal replacement therapy device: a preliminary study. Asaio J 2014;60(5):564-569.

34. Forster C, Schriewer J, John S, Eckardt K-U, Willam C. Low-flow CO2 removal integrated into a renal-replacement circuit can reduce acidosis and decrease vasopressor requirements. Crit Care 2013;17(4):R154.

35. Moerer O, Harnisch LO, Barwing J, Heise D, Heuer JF, Quintel M. Minimal-flow ECCO2R in patients needing CRRT does not facilitate lung-protective ventilation. J Artif Organs 2019;22(1):68-76.

36. Allardet-Servent J, Castanier M, Signouret T, Soundaravelou R, Lepidi A, Seghboyan JM. Safety and efficacy of combined extracorporeal $\mathrm{CO} 2$ removal and renal replacement therapy in patients with acute respiratory distress syndrome and acute kidney injury: the Pulmonary and Renal Support in Acute Respiratory Distress Syndrome Study. Crit Care Med 2015;43(12):2570-2581.

37. Nentwich J, Wichmann D, Kluge S, Lindau S, Mutlak H, John S. Low-flow $\mathrm{CO} 2$ removal in combination with renal replacement therapy effectively reduces ventilation requirements in hypercapnic patients: a pilot study. Ann Intensive Care 2019;9(1):3.

38. Schmidt M, Jaber S, Zogheib E, Godet T, Capellier G, Combes A. Feasibility and safety of low-flow extracorporeal $\mathrm{CO} 2$ removal managed with a renal replacement platform to enhance lung-protective ventilation of patients with mild-to-moderate ARDS. Crit Care 2018;22(1):122. 